\title{
Assessing Speech Acts of Curses and Prayers in Persian
}

\author{
Shahla Sharifi \\ Linguistics Department, Ferdowsi University of Mashhad, PO box 91779-48974, Mashhad, Iran \\ Email: sh-sharifi@um.ac.ir \\ Shima Ebrahimi (Corresponding Author) \\ Linguistics Department, Ferdowsi University of Mashhad, PO box 91779-48974, Mashhad, Iran \\ Email: shima.ebrahimi@yahoo.com
}

\begin{abstract}
Speech acts are of great importance primarily within the bounds of semantics and should be on the basis of mutually shared background information between hearer and speaker. Curses and prayers are commonly used in everyday language. Whenever someone does a favour to us, we may say a prayer to God for him/her. We may curse at someone for making us angry or sad. By and large, we express our inner feelings and attitudes towards the hearer through saying prayers or curses; therefore, they are involved in expressive speech acts. The present article delivers a special classification of prayers and curses which are as follows: a) prayers and curses which are closely associated with our culture, tradition and religion; b) prayers and curses which have been progressed and produced gradually and no specific cultural root can be traced for them. This type of speech acts is itself classified into two categories: the first one is composed of prayers and curses which are frequently used by children in different contexts and the second category comprises those prayers and curses which English speakers have in common with Persian speakers.
\end{abstract}

Index Terms - speech act, expressive acts, prayer, curse

\section{INTRODUCTION}

Semantics is one of the considerable topics of linguistics which in the past few years there has been a remarkable growth of research on it. It also covers the scope of the study of speech acts.

The contemporary use of speech acts goes back to J. L. Austin's introduction of this term in How to Do Things with Words published in 1962. Speech acts are mostly taken to include some acts such as ordering, promising, thanking and so forth which can be distinguished from each other through different aspects of the speaker's intention.

By and large, speech acts are communicative acts in which the content of communication is intended. For instance, declarative sentences are supposed to express the speaker's attitudes and emotions; directives cause the hearer to take a particular action and show the speaker's intention; apologizing also indicated the speaker's regret.

Due to the fact that we show our anger through curses and our satisfaction through prayers for somebody, curses and prayers can be considered as speech acts.

According to different dictionaries, there are lots of definitions for curses and prayers. For example, Dehkhoda Encyclopaedia defines them as follows:

Curse: a payer asking that God brings misfortune to someone; an imprecation; an execration; the opposite of a blessing; a denunciation; a remonstration

To curse: asking that God brings misfortune to someone; to imprecate; to execrate; to stone somebody

Prayer: asking God for your needs to be fulfilled, the plural form of prayers in Arabic; a reverent petition made to God; imploring God; making a request of God to help us or others; an effort to communicate with God

Based on Nafisi Dictionary, these two words mean:

Curse: an appeal for misfortune to befall someone; damnation; hatred; abusiveness; reproach; blaming; ridicule

To curse: requesting for harm from God to come upon one; to keep away; being annoyed and furious by someone's offensive statements

Prayer: asking God for your needs; an invocation; an activity of religious worshipping; adoration; a devout petition to God; an earnest request of God for help with intense yearning; a sequence of words which has been derived from different prophets and helps to start a spiritual communication with God and people utter it when they want to be forgiven for their sins

Anvari Dictionary has presented the following definitions for the curse and the prayer:

Curse: a prayer for misfortune, injury, misery or death to befall someone

According to Moein Dictionary, prayer means reading some sequences of words at specific times which have been derived from different prophets and imams to be forgiven for their sins; an earnest request of God for their needs; 
religious and spiritual communication with God; an enthusiastic praise unto God; giving compliments to God; imploring God; it also means asking God for misfortune to befall someone.

The present article discusses different classifications and functions of prayers and curses in various contexts. So, it aims to answer the following questions:

1. Which classifications of prayers and curses can be presented?

2. Is there any specific root associated with the existing prayers and curses in the society?

3 . Is there any age restriction on the mentioned speech acts?

4. Are all prevailing prayers and curses culture-bound?

Owing to the fact that the issue of prayers and curses can be discussed under the title of speech acts, it is better to elaborate speech acts at first.

Speech acts have become popular through the posthumous publication of J. L. Austin's How to do things with word in 1962. O'Gray (2005, p. 304) states that according to Austin's theory, speech acts are consisting of three levels and can be analyzed based on these three functional units of communication: 1) prepositional or locutionary meaning, which is the literal meaning of what is said; 2) illocutionary meaning, which is the social function of what is said like an indirect request, refusal, praise or complaint; 3) perlocutionary meaning, which is the effect of what is said.

It seems that prayers and curses can be taken to include as perlocutionary acts, since they have some effects on the hearer.

Speech acts have subsequently become extremely influential, especially through the Searle's publication in 1976. He has set up the following classification of speech acts:

1. Commissives: they are speech acts which commit the speaker to doing something in the future, e.g. promising, vowing and threatening

2. Declarations: they are speech acts that alter the reality in accord with the proposition of the declaration

3. Directives: they are speech acts that make the hearer perform a particular action, e. g. requesting, ordering, inviting or suggesting

4. Expressives: they are speech acts that express the speaker's attitudes and feelings towards the proposition, e. g. excuses, complaints, thanks and congratulations

5. Assertives: they are speech acts which describe the situation and commit the speaker to the truth of the expressed proposition, e. g. assertions, claims and reports

Owing to the fact that few studies have been done providing data on the issue of prayers and curses, this article has been carried out.

\section{The InVESTIGATION OF PRAYERS AND CURSES In PERSiAn LANGUAGE}

Prayers are also accompanied with a positive connotation. It is a request of God to help us or others and fulfill our needs. Through a prayer, someone asks God to bring fortune to a person but in a curse, God is asked to bring a misfortune to a person. As a matter of fact, someone appeals for agony, torment and misery to befall a person through a curse and in this way, they get their revenge on whom has harmed or offended them. A curse is actually a prayer but a negative one which keeps them away from merit, bliss and happiness. If a curse is opportune and proper, it may be answered and fulfilled by God.

In general, prayers and curses can be classified into the following groups:

A) Prayers and curses which are closely associated with a country's culture, traditions, customs and religion; they vary from one country to the other and seem meaningful just for the native speakers.

B) Prayers and curses which have been progressed and produced gradually and no specific cultural root can be traced for them. They are understood by both natives and non-natives who are aware enough of the country's culture and customs. This type of speech acts is classified into two categories:

1. Childlike speech acts

Prayers and curses which are simple and intelligible and are frequently used by children in different contexts, since they do not need a high knowledge of the country's culture or tradition, so they are even understood by children.

2. Non-culture-bound speech acts

Prayers and curses which can be understood without the same cultural background and they are universal and equal in different languages with dissimilar cultures. For example, prayers and curses which English speakers have in common with Persian speakers.

Some examples of the first group (A) will be presented below.

1) I hope your glass of life is broken

Glass of life is a mythological term which goes back to the legends in which the protagonist won the victory over devils and demons. In these myths, demons possessed a glass of life and the protagonist had to find and break it to overcome the battle. If someone uses this expression as a curse, he has made an analogy between that person and demons, so he asks God to bring death to that person.

2) I hope your corpse is buried in different graves as you are lay dying

There are some hadiths in Islam which refer to some angels- Naghale angels- who are responsible for moving a dead person after the burial to a better or worse place. This curse proves that the speaker has the hope of a restless and 
agonizing life for the hearer after death. This curse has roots in the religion of Islam, so it may not be intelligible for other cultures and religions.

3) I wish that the fire falls on your grave

Muslims believe in two angels named Nakir and Munkar meaning the Denied and the Denier who are responsible for asking some basic questions apropos of Islam and test the faith of the dead on the first night of his death. If the deceased person cannot answer correctly, he will be chastised and his grave will be covered by the fire.

4) May God rest his soul in peace

Muslims believe that, after death, a person's soul will pass through another stage and they need to be forgiven. Based on Islam, this honour is only bestowed on the dead by God; therefore, Muslims say prayers for a dead person to be encompassed by the generosity of God. Such belief also exists in Christianity, but the difference is that Christians ask God for peace and not forgiveness.

5) May you are lucky enough to have a blissful life

Believing in good and bad luck goes back to the Iranian culture. We ask God to bring fortune to a person through this prayer.

6) I wish that God does not forgive your faults

In Islam, it is believed that at the Resurrection Day, all people will be restored and resurrected to the way they were before they died. They will be held accountable for their deeds and will be judged by God. Through this curse, the speaker asks God not to forgive the hearer when he is looking into their deeds. The opposite of this expression is "May God forgive your faults" which is considered as a prayer.

7) May God preserve it for you

God is the source of all our blessings and properties, so everything human beings possess is the result of his generosity and kindness. The speaker says a prayer for the preserve of the hearer's blessings.

8) May God forgive me before death

Muslims believe that if a person is forgiven and then he dies, he will be released from this world's agonies. So, through this prayer, a person makes a reverent request of God to forgive him before his death.

9) I hope that God brings you health and healing

The origin of this prayer can be found in one of the Prophet Muhammad's Hadith. According to this Hadith, God wipes off some of a Muslim's sins for every misfortune, illness, agony, pain, or hurt that afflicts him, even if the hurt has been caused by the pricking of a thorn in his hand. The speaker asks God for the hearer's health through saying this prayer.

10) I hope that you sleep at night, and cannot wake up in the morning

The religious etymology of this expression can clarify its meaning. In Hadith, it is explained that sleep is a king of temporary death. Through this curse, the speaker asks God to make this temporary death permanent. As a matter of fact, he desires for the hearer's death.

11) May God make you the prophets' companion in Paradise

It is mentioned in the Holy Quran that prophets and their companions will live in happiness at the seventh level of Paradise. The speaker makes a petition to God to have eternal mercy on the hearer.

12) God help you

God is human beings' refuge and helper and everybody needs him. Through this prayer, the speaker asks God to help the hearer. However, this prayer may have a negative connotation when someone has done something wrong. If the expression is used in such a situation, it means that God forgive you.

13) Live long with each other as you grow old together

This prayer has a positive connotation and means that the speaker says a prayer for a couple to live with each other until they are old and die. This expression may be accompanied with a negative meaning in other cultures, since aging and becoming older may have negative meaning.

14) Hello and goodbye

The word 'hello', which is also a sentence, is the sign of praying for someone to be healthy and delighted. In addition, through saying the word 'goodbye', the speaker requests God to protect the hearer from danger.

15) Don't be tired in your heart

This prayer is commonly said as an answer on 'don't be tired' when someone is working hard or someone who has just finished his work. Through this expression, the speaker asks God to keep the hearer away from pain, regret and hatred which can bother his heart.

16) I wish that you will be answered by God

This curse is used when someone has done something bad to the speaker. It means that the hearer will be retaliated by God and he will be punished. According to the Holy Quran, the smallest and biggest deeds can be seen and answered by God.

17) Be in God's hand

God's hand refers to the God's kindness and blessing to which all people need. Through this prayer, the speaker makes a request of God to help the hearer.

18) Touch the soil, may God change it into the gold 
Alchemy has been recognized as a science which contributed to the development of modern chemistry. In the past, alchemists claimed to have the capability of turning soil into the noble gold. This prayer can be also meant as 'I hope you become rich'.

19) I hope I eat your Halva

Halva is an Iranian term which refers to a kind of sweet served for funerals or mourning ceremonies. This curse means that the speaker wishes the hearer dies, then he goes to his funeral and eats his Halva. It is a metaphor in which the speaker asks God to bring earlier death to the hearer.

20) I hope you go and never come back

In the past, there were lots of adversities in travelling. People could not travel as easy as today, so making a long journey was so perilous. Through this curse, the speaker appeals to God to bring misfortune to the hearer in a way he cannot return from his journey. This impossibility of returning can be the consequence of death or difficulties.

Here, some examples of the second group (B) will be mentioned. Second group is consisting of prayers and curses which have been progressed and produced gradually and no specific cultural root can be traced for them.

By and large, most people try to show their fury and rage through curses when they are unable to do anything. In this way, they ask God to take their revenge on tyrants and enemies.

Issues of death, destruction and inexistency can be seen in almost all curses. In fact, the speaker expresses his anger by asking God to bring death, misfortune, destruction and perdition to the hearer, since death is the end of life.

Through some curses, the speaker asks God to cause a physical damage to the hearer, e. g. he asks God to break the hearer's hand or back or get cancer. However, breaking the hand cannot be accepted as a curse in all cases unless the speaker has been physically hurt by the hearer and due to the fact that the speaker is incapable of taking revenge, he makes this request of God.

Due to the fact that these prayers and curses have been personally made, they do not have any specific cultural root. Some examples can be seen below.

1) I wish that you have bad luck in whole your life. Bad luck is the same in different cultures.

2) I hope to see your death sooner

3) I hope to hear the message of your death

4) I hope to see your grave

5) I hope that you are cut off in the prime of your life

6) I hope that your hand is broken

7) I hope you die

8) I hope that you cannot enjoy your youth

9) I hope you go from riches to rags

10) I hope you cannot get any of your wishes

11) I hope your parents never stop grieving over your death

12) I hope you die and your mother mourn your death

13) I hope you get an incurable disease

14) I hope you become reduced to beggary

15) May God give you more money and blessings

16) I hope you live long

17) I hope God gives you whatever you desire

18) God damn you

Childlike speech acts

These are prayers and curses which are simple and intelligible and are frequently used by children in different contexts. It should be pointed out that children do not have a clear perception of curses and mostly they just imitate adults around them without understanding the exact meaning of the curse. However, since these speech acts do not need a high knowledge of vocabulary, sentence structure, culture and tradition, they are sometimes easily understood by children. The following prayers and curses are considered as childlike speech acts.

1) I hope your hand is burnt

2) Go to hell

3) I hope you die

4) I hope that God kills you

5) I hope you fail your exam

6) I hope that God changes you into a beetle

7) I hope your mom hits you

8) I hope a bee stings you

9) I hope your coloured pencils are lost

As it is obvious, these speech acts' language is so simplistic and understandable for children. They may use them in different situations without any intention when they get angry.

Non-culture-bound speech acts 
Owing to the fact that non-culture-bound prayers and curses are universal, they can be understood by people whose cultural backgrounds vary from each other. For example, prayers and curses which English speakers have in common with Persian speakers are belonged to this group.

It should be mentioned that although their origin is the same in these speech acts, they may be presented by various vocabularies and structures in different cultures.

This slight difference can be the consequence of dissimilar religions. For instance, in Islam, through the prayer 'May God forgive him' we ask God to forgive a deceased person, but the similar prayer which exists in Christianity is ' May God rest him in peace' which refers to the deceased's peace and repose that is different from forgiveness. There are some examples of this kind below.

1) You reap what you sow

This expression means everything that happens to you is the result of your own actions, and you cannot escape the consequences of your actions. So, if God punishes or rewards you, they are both the result of your deeds in this world.

2) God bless you

3) May God rest him in peace

4) God damn him

5) Get out

6) Come to a bad end

7) It is not worth a damn

8) God damn you

9) Die early in life / Be cut off in the prime of your life

10) Bad luck to you

11) I hope you kill the goose that lays the golden egg

12) May God speed you

\section{DISCUSSION AND CONCLUSION}

As it was adverted in this article, speech acts are classified into various categories. One of these classifications has been set up by Searle. He has introduced five categories of speech acts which one of them is expressive speech act that expresses the speaker's attitudes and feelings towards the proposition. Prayers and curses are considered as expressive speech acts since they reveal the speaker's feelings.

In this study, first, prayers and curses were classified into the following groups: a) Prayers and curses which are closely associated with a country's culture, traditions, customs and religion; they vary from one country to the other and seem meaningful just for the native speakers. And b) Prayers and curses which have been progressed and produced gradually and no specific cultural root can be traced for them. This type of speech acts was itself classified into two other groups: 1) Childlike speech acts which are simple and intelligible and are frequently used by children in different contexts, and 2) Non-culture-bound speech acts which can be understood without the same cultural background and are universal in different languages with dissimilar cultures. For example, prayers and curses which English speakers have in common with Persian speakers. In the group (a), it was mentioned that some of prayers and curses are closely associated with Iranian culture, tradition and religion. In the group (b), some speech acts which are mostly used by children when they get angry were discussed. It was mentioned that these speech acts are not real curses or prayers due to the fact that children do not have a clear conception of them and they may just imitate adults through using these expressions. Then, some prayers and curses which are equal between English and Persian language have been explained. Therefore, prayers and curses can be found in all languages with some trivial differences which are the result of their various customs and cultures.

On the basis of what has been investigated in this study, it can be concluded that human beings utter some negative or positive statements at the time of happiness or sadness when they are unable to do anything else.

It should be pointed out that the number of these sentences is going to be gradually reduced due to their close association with superstition. According to the conducted interviews, the aforementioned prayers and curses have been mostly used by the aged whose beliefs have roots in the past.

\section{REFERENCES}

[1] Austin, J. L. (1975). How to Do Things with Words. Massachusetts: Harvard University Press.

[2] Black, J.W., Stratton, C.S., Nichols, A.C., \& Chavez, M.A. (1985). The use of words in context: The vocabulary of college students. New York: Plenum.

[3] Caultharb. M. (1992). Advances in Spoken Discourse Analysis. London: Routledge.

[4] Clark, Herbert. H. (1996). Using Language. Cambridge: Cambridge University Press.

[5] Crystal, E. (1985). A Dictionary of Linguistics and Phonetics. New York: Basil Black well Ltd.

[6] Cruse, D.A. (1986). Lexical Semantics. Cambridge: Cambridge University Press.

[7] Dehkhoda, Aliakbar (1994). Dehkhoda Encyclopedia. Iran: Tehran University Publication.

[8] Fann, K. T. (1969). Symposium on J. L. Austin. London: Routledge \& Kegan Paul; New York: Humanities Press.

[9] Firth, J. R. (1967). Modes of Meaning. London: Oxford University Press. 
[10] Foote, R, \& Woodward, J. (1973). A preliminary investigation of obscene language. Journal of Psychology, 83, $263-275$.

[11] Forguson, L. W. (1981). Locutionary and Illocutionary Acts' in Berlin et al. Essays on J.L. Austin, 160-185.

[12] Hall, W.s., Nagy, W.E., \& Linn, R (1984). Spoken words: Effects of situation and social group on oral word usage and frequency. Hillsdale, NJ: Erlbaum.

[13] Jay, T.B. (1992). Cursing in America. Philadelphia: John Benjamins.

[14] Lobner, Sebastian. (2002). Understanding Semantics. Cambridge: Cambridge University press.

[15] Lyons, John (1997). Semantics. Cambridge: Cambridge University press.

[16] O'Grady, W., Dobrovdsky, M. and Aronoff, M. (2006). Contemporary Linguistics: An introduction. Translated by Darzi. A Tehran: Samt Publication.

[17] Safavi, Kourosh (2000). Semantics. Tehran: Soure Mehr Publication.

[18] Searle, J. R. (1976). A Classification of Illocutionary Acts. Language in Societies 5, 1-2-3.

[19] Searle, John R. (1968) . Austin on Locutionary and Illocutionary Acts. The Philosophical Review 77:405-424.

[20] Stubbs, M. (1983).Discourse Analysis. Oxford: Basil Blackwell Ltd.

Shahla Sharifi is an associate professor in linguistics. She is currently in Ferdowsi University of Mashhad, where she teaches some courses like typology, pragmatics and morphology for MA and Ph.D students. She has done her PhD in linguistics in Ferdowsi University of Mashhad. Her MA thesis was in GB framework and her PhD dissertation was on word order typology. Her main areas of interests are typology, pragmatics and morphology.

Shima Ebrahimi is an MA holder in linguistics. She received her BA degree in English Language and Literature in 2007 and MA degree at the Ferdowsi University of Mashhad in 2012, in the field of General linguistics. Her main research interests are semantics, pragmatics, examining the theoretical and practical issues in discourse analysis. 